\title{
Moda, fotografia e memória afetiva em Seydou Keïta (1948-1962)
}

Fashion, photography and affective memory in Seydou Keïta (1948-1962)

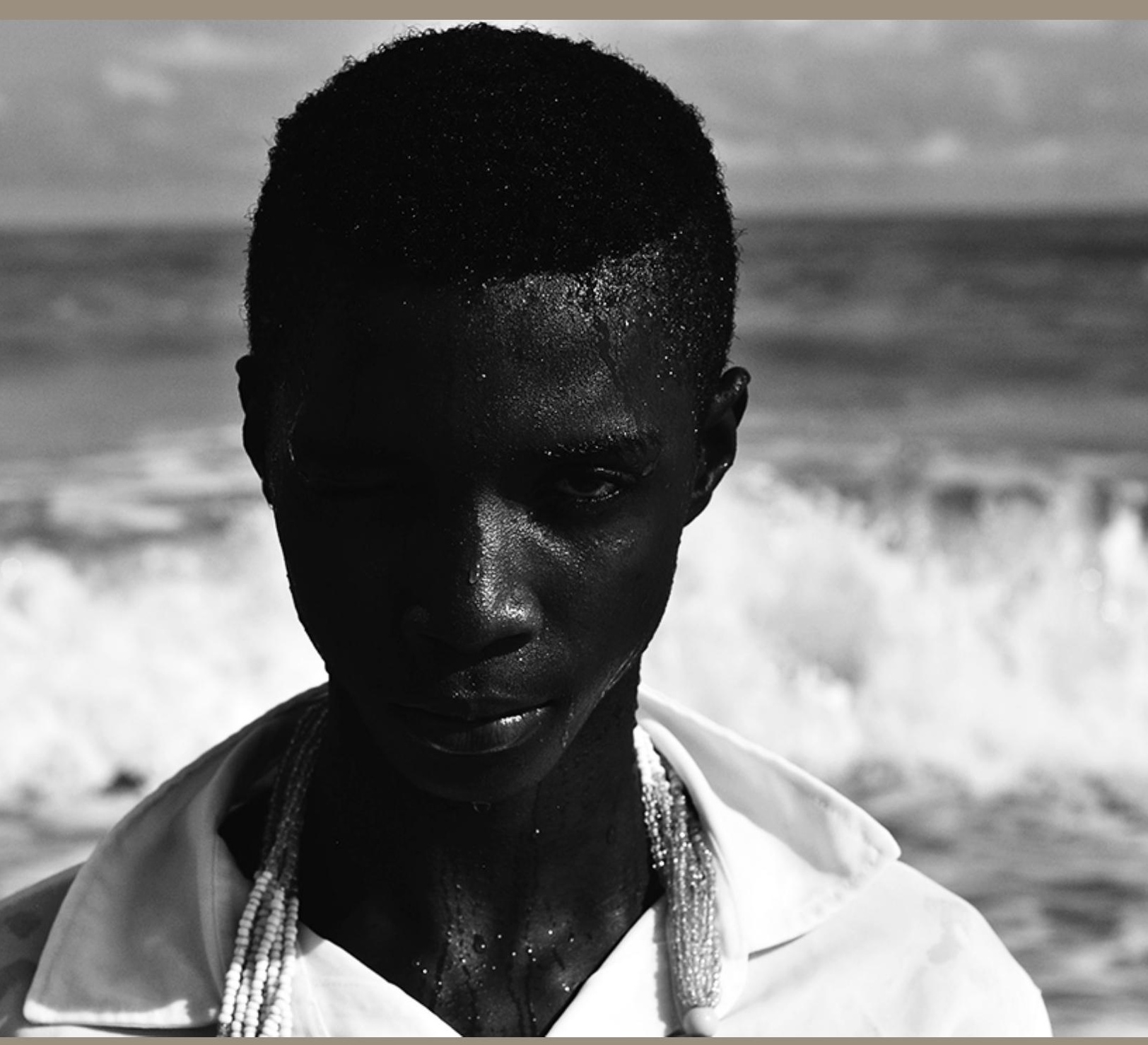




\section{Rafael Tassi Teixeira ${ }^{1}$}

ORCID: https://orcid.org/0000-0001-7137-0904

[resumo] Este trabalho parte das fotografias de Seydou Keïta produzidas entre os anos de 1948 e 1962 (segunda etapa da sua realização, posterior ao período inicial, de 1935 a 1948) em um estúdio em Bamako, no Mali. Diante de uma lente carregada de afetos, a dinâmica fotográfica se insere em uma espécie de jogo estético e social que franqueia aspectos compositivos (enquadramento, distância, fundo, pose, gesto) e etnográficos em um refinado trabalho de ressignificação das influências coloniais e das modas ocidental e africana encenadas nos retratos de estúdio. 0 fascínio pelo moderno e a dignidade ancestral surgem em fusões estéticas, de um apurado gesto de organização fotográfica que delimita a imagem social entre reapropriação criativa de estilos europeus e reenergização das tradições indumentárias africanas. A série de fotografias aqui apresentada abraça a característica composicional dos retratos de Keïta, estabelecendo uma ativa correspondência entre a transmissão de genealogias, a multiplicidade de referências culturais e a encenação da moda como um aspecto de narrativização discursiva, da autoafirmação da etnicidade pessoal.

\section{[palavras-chave] Fotografia. Moda africana. Etnicidade. Seydou Keïta.}

[abstract] This work is based on photographs of Seydou Keïta produced between 1948 and 1962 (second stage of his photos, after the initial period of 1935-1948) in a photographic study in Bamako, Mali. Faced with a lens loaded with affections, the photographic dynamics is part of a kind of aesthetic and social game that opens up compositional aspects (framing, distance, background, pose, gesture) and ethnographic aspects in a refined work of reframing colonial and fashion influences western and African staged in the studio portraits. The 'fascination with the modern' and ancestral dignity emerge in aesthetic 'fusions' in a refined gesture of photographic organization that delimit the social image between the 'creative reappropriation' of European styles and the reenergization of African dress traditions. The series of photographs chosen here embraces the compositional characteristic of Keïta's portraits, establishing an active correspondence in the transmission of genealogies, in the multiplicity of cultural references, and in the staging of fashion as an aspect of discursive narrativization of the personal ethnicity.

[keywords] Photography. African fashion. Ethnicity. Seydou Keïta.

Recebido em: 09-03-2020

Aprovado em: 31-07-2020

\footnotetext{
Pós-Doutor em Cinema e Audiovisual (Universitat Autònoma de Barcelona - UAB; 2018). Doutor em Sociologia pela Universidad Complutense de Madrid (UCM; 2004). Professor Adjunto do Mestrado em Cinema e Artes do Vídeo e professor adjunto da Unespar, Campus Curitiba II. Professor do Programa de Pós-Graduação Mestrado e Doutorado em Comunicação e Linguagens da Universidade Tuiuti do Paraná (PPGCOM\UTP). Líder dos Grupos de Pesquisa (CNPq) Desdobramentos Simbólicos do Espaço Urbano nas Narrativas Audiovisuais (GRUDES) e Eikos (Imagem e Experiência Estética). E-mail: rafatassiteixeira@hotmail.com. Lattes: http://lattes.cnpq.br/9074237042190064.
} 


\section{Introdução}

Nascido em Bamako (Mali, África Ocidental), em 1921, Seydou Keïta começa suas atividades fotográficas depois de inicialmente seguir o pai na prática da carpintaria. A relação com elementos da fotografia ocorre por influência de um tio materno, logo nos primeiros anos da década de 1930, quando Seydou desenvolve seu aprendizado com Pierre Garnier, proprietário do Photo-Hall Soudanais ${ }^{2}$. No decorrer desse período, e até o fim da Segunda Guerra Mundial, sua fotografia é estilisticamente influenciada pelo trabalho junto à Mountaga Dembélé, um professor primário que o auxilia no domínio das técnicas fotográficas e manipulações químicas, contratando o jovem para trabalhar em seu estúdio e encaminhando-o na profissão (LEENHARDT, 2018).

Depois dos primeiros anos de formação, de 1930 a 1940, a atividade fotográfica passa a ser rentável para Keïta, em uma África que aos poucos começa a emergir do contexto colonial, mas ainda sob os auspícios dos invasores e a forte influência europeia. A fotografia, nesse contexto de primeiro esboço de independência, é fundamental para a busca de autonomia representativa (sobretudo, a partir de um imaginário próprio, menos refém da presença museológica e etnográfica). Menos subordinada ao olhar estrangeiro e etnográfico, e menos prisioneira da apropriação simbólica e da violência exotizante vinculada, por exemplo, ao cartão-postal (muito comum nas fotografias do fim do século XIX e do início do XX), a fotografia africana emerge do enfrentamento paulatino de seu primeiro contexto de autoridade antropológica - quando ainda a etnologia, segundo PINK (2001), começava a criticar o movimento de antropometrização das sociedades africanas pela prática evolucionista no fim do século XIX e no início do XX³ .

Keïta é um dos fotógrafos que rompe com esses discursos ao associar as figuras antropológicas com o envolvimento pessoal e afetivo dos retratados. Participam dos retratos os sujeitos tradicionais e suas derivas simbólicas, reorganizando os elementos etnográficos (o papel frontal da pose e o didatismo da imagem) em uma fotografia de estúdio que versa,

\footnotetext{
Garnier é importante para a formação inicial do artista, pois possuía um estúdio com vários acessórios fotográficos e vendia seus materiais importados (ou artesanalmente adaptados) para toda a região do oeste africano; com a câmera fotográfica que ganhou do tio (um caixote de 6 × 9 (por favor, qual é a medida? cm?) adaptado para fotos), o menino pôde aprender os primeiros passos da fotografia e entrar em contato com vários fotógrafos malinenses e senegaleses da época, além de experimentar o manejo dos equipamentos e de técnicas de revelação utilizadas no período. A produção de Keïta, nesse sentido, nasce marcada por forte influência da fotografia de estúdio africana de então, que sublinhava a perfeição atemporal nos retratos e a cumplicidade entre identidade, fotógrafo (africano) e modelo. A maior parte das primeiras fotografias realizadas pelo jovem Keïta nesse período foram perdidas, segundo o próprio artista (LEENHARDT, 2018).

${ }^{3} 0$ retratismo etnográfico por parte dos primeiros fotógrafos e etnólogos europeus tinha como principal preocupação uma fotografia derivada de exigências antropológicas: interessava-se pela marcação dos corpos dentro de referências culturais delimitadas. A ênfase era destacar uma imagem etnológica que se antepunha à perspectiva do indivíduo dentro do grupo social (por isso, a representação artística do corpo humano ainda não era destacada). O principal motivo na captura, tal como escreve Edwards (1997), era produzir uma escolha eminentemente etnográfica da representação. Buscava-se, sobretudo, o congelamento de elementos simbólicos e um corpo por vezes racializado e distante. Já nas fotografias realizadas a partir dos anos 1930 (PINK, 2001), a preocupação antropológica passa a interessar-se por outros elementos compositivos, como a valorização da pessoa humana e a performance individual.
} 
invariavelmente, sobre a foto como um sistema de subjetivação que transporta o indivíduo à referência imaginária. 0 refinado trabalho de pose é acolhido na esfera da identidade, fugindo de seu endereçamento ilustrativo e expandindo o retrato em uma convicção da forma fotográfica. Com os anos de estúdio, tal efeito se converte em um repertório ditado tanto pela simetria e pela elegância das composições como pela abertura artística ${ }^{4}$.

0 resultado é um apelo da imagem à convicção da sua independência. As fotos de Keïta, assim, são abraçadas por uma estética desejante, que descontrói os paradigmas visuais anteriores em uma apresentação sensível dos corpos e seus sentidos biográficos. 0 espaço da moda e do cinema tornam-se referências fundamentais, preconizadas na circulação das revistas europeias, especialmente entre os clientes mais jovens. Símbolos de distinção e de consumo, como motocicletas, roupas e adereços ocidentais, movem-se como motivos transformadores nos registros dos personagens, contracenando com elementos etnológicos. 0 fotógrafo parece respeitar o sonho de transformação desses jovens africanos retratados, transportando para a imagem uma negociação sutil entre os aspectos étnicos e a dinâmica da moda metropolitana e da cultura de massas que chegavam na África do pós-guerra.

Toda a convergência de elementos é construída na afetividade dos registros, no encontro de visualidades e nas ressignificações plásticas, nos motivos biográficos que esperam que a história de vida esteja tanto na memória ancestral como no anseio de transformação individual. Suas tomadas, feitas em estúdio, priorizam a vontade pessoal dos sujeitos da imagem com um acolhimento delicado e instrutivo por parte do artista. 0 arbítrio da fotografia se dá, no limite, em um campo de possibilidades plásticas renegociadas na rede de ressignificações provenientes da beleza do endereçamento, da vigência das roupas e dos adornos, do dress code e do esforço de incorporação de influências e desejos predominantes. O terno, a gravata, as bolsas de couro, o relógio de pulso e as canetas esferográficas associam-se, sensivelmente, às túnicas e aos chapéus coloniais, à indumentária tradicional e às formas étnicas de arranjo capilar. Em um arco de possibilidades que ensaia o indivíduo e sua formação cultural dentro de uma estética em constante negociação, as lentes de Keïta procuram a capacidade icônica transformável. Possibilitam ensejar a alegria junto ao novo e seus signos políticos aplicados na autonomia a ser buscada, reivindicando, em uma galeria de retratos, o envolvimento do passado com o futuro - a emancipação da pessoa, a possibilidade da memória, o peso da tradição e à deriva do eu nas narrativas próximas, valorizadoras, coexistentes, íntimas ${ }^{5}$.

No olhar de Keïta, a moda atua na fotografia como uma espécie de orientação da experiência social e emocional. Ela participa na construção da imagem, salvaguardando o elo que existe entre o passado e o presente, transformando, sob uma mesma matéria, a chance

\footnotetext{
${ }^{4}$ Aberturas utilizadas, por exemplo, no investimento tridimensional de algumas fotografias: uma parte do corpo em perspectiva mais avançada, um gesto particular das mãos, um adereço não convencional nos códigos de vestuário.

5 A atmosfera festiva dos primeiros ensaios do país que conquistaria a liberdade a partir da década de 1960 ainda está longe de ser totalmente exposta nas fotografias sutilmente controladas de Seydou. Será Malick Sidibé, discípulo de Seydou Keïta, quem reorganizará a memória da independência em fotos na etapa futura, enfatizando o orgulho malinense a partir da liberdade colonial e inscrevendo a fotografia malinense em capturas mais livres (valorizando a exaltação da felicidade, as danças e a espontaneidade dos corpos).
} 
da identidade, da autoetnografia, da reflexividade pessoal. Revela a prática criativa de poder operar sobre a própria dimensão performativa e sobre a vontade dividida entre o tradicional e o moderno (na capacidade política de sonhar com liberdade). As imagens se relacionam, nesses termos, tanto ao parentesco como à individualidade. Expressam uma dignidade partilhada, o orgulho da autodeterminação, as lentes africanas antes que as estrangeiras, a atmosfera de conhecimento, de valorização dos corpos, posturas, jogos de cena. Trançam o indivíduo com sua história, em um realce possível e imaginário, na delicadeza da figuração dramática, em seu efeito partilhado, icônico, perdurável.

\section{Seydou Keïta na história africana da fotografia}

Já no início do século XX, a presença europeia passa a ser contrastada com o olhar africano em busca de suas origens, revelada no retrato fotográfico - especialmente naquele realizado em estúdios. 0 fim do isolamento cultural encaminha múltiplas sociedades africanas para a dissociação do passado colonialista, e o trabalho dos primeiros fotógrafos da região está de certa maneira menos preso ao dilema representacional do passado: costumbrismo x produção individual. Certa cultura da imagem, como escreve Leenhardt (2018), direciona, naquele momento, as manifestações imagéticas para uma renovação parcial de modelos estéticos e etnográficos, que coincidem com o desejo de autonomia dos sujeitos da imagem, dos realizadores da fotografia, da coexistência de modulações estéticas. É preciso destacar, dentro desse contexto, a profissionalização dos fotógrafos, como Seydou, e também o desejo de diferenciação social das famílias retratadas. Há uma vontade expressa, entre fotógrafos e fotografados, de singularização individual, de exibição das roupas e dos signos de consumo. Por parte do profissional, o ensaio sobre a prática do ofício, da parte dos membros das famílias que buscavam o estúdio, a valorização da posição social.

Nesse sentido, a fotografia torna-se um dispositivo central de encaminhamento da expressão popular, conectando as massas ao repertório tradicional, a cultura de origem e a necessidade de autoafirmação particular - na demanda recém-instalada por expressão e autonomia representativa ${ }^{6}$. 0 contexto de desafricanização parcial, já depois da Segunda Guerra Mundial, modula o processo de identificação dos primeiros fotógrafos africanos a partir de elementos cada vez mais transculturais, avançando sobre a prática de reprodução retratista herdada dos viajantes do século XIX e dos antropólogos do início do século XX. 0 forte revisionismo do domínio colonial e, ao mesmo tempo, o começo da fotografia de estúdio começam, destarte, a escrever com força a necessidade de uma identidade africana à luz de uma modernidade que se projeta já na primeira metade do século XX.

Coexistem na época, modulações correlacionadas à antropologia junto às tentativas iniciais de libertação do contexto de apropriação simbólica. Utiliza-se o ensaio fotográfico

\footnotetext{
- 0 trabalho de Keïta, alinhado com o de outros fotógrafos importantes para a criação de uma referencialidade própria no estilo da fotografia africana (Malick Sidibé, Mountaga Traoré, Youssouf Cissé, etc.), nesses termos, desestabiliza a autoridade etnográfica dos retratistas europeus e enseja uma fotografia carregada de afetos, do pathos expressivo concentrado na pessoa e na exaltação da autonomia individual. Uma fotografia que, no bojo das relações entre fotógrafo e retratado, acaba replicando menos o sistema evidenciativo e controlado da fotografia etnológica (EDWARDS, 1997), privilegiando a possibilidade sensível e performativa da fotografia realizada por africanos.
} 
para colapsar a distância entre os corpos retratados e o olhar estrangeiro - e para aproximar fotógrafo africano e fotografado da África. A etapa etnográfica ainda é algo vigente na forma da escrita fotográfica dos primeiros fotógrafos africanos. Mas o olhar antropológico está menos presente na ordem da captura, pois os retratos que surgem na lente dos pioneiros africanos são menos dependentes da determinação tipológica anterior. 0 foco no rosto e na dinâmica visual, a expressividade dos retratados, a suave valorização do repertório tradicional adejado à subjetividade do retratado conciliam na foto um clima de intimidade e dignidade compartida ${ }^{7}$.

\section{FIGURA 1}

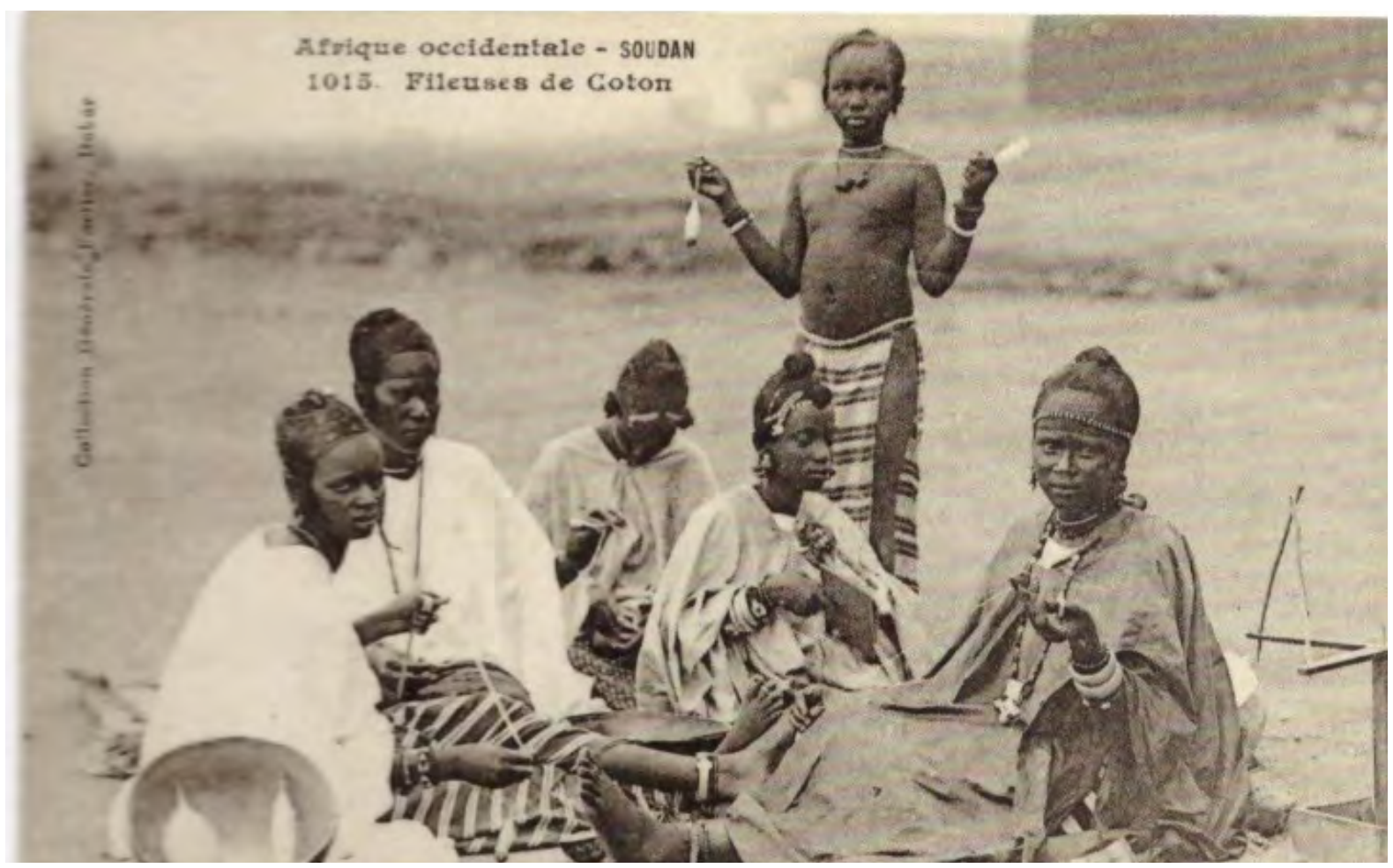

FONTE: EDMOND FORTIER. Fiandeiras de algodão. África Ocidental Francesa, Sudão, s.d. ${ }^{8}$.

\footnotetext{
Os retratos de Meïssa Gaye e Mama Casset, por exemplo, são significativos nesse período de espraiamento de uma fotografia que perspectiva a identidade africana e sua característica sui generis: o fotógrafo mergulha na cena e cria uma instância perdurável, valorizando as personas visuais, o rico espelhamento dos laços entre o passado e o presente (expostos, por exemplo, nas várias fotografias de pessoas com indumentária tradicional capturadas diante de paredes cheias de retratos de parentes) e os arranjos de estúdio. Há, também, uma longa tradição de autoras e autores anônimos da qual Seydou Keïta é proveniente, sobretudo na realização da intensidade estésica e íntima do retrato, no efeito configurativo do posado, que diagrama os corpos em situações memorialísticas; também é significativa como procedimento a leitura pausada das relações entre as manifestações tradicionais e as caraterísticas humanas: rostos e mãos, muitas vezes com anéis e adereços, são efemerizados em capturas persistentes, às vezes emolduradas em contraste com os fundos repletos de imagens, em outras com a neutralidade da tela branca ou quadriculada; é como se a fotografia registrasse, naquele então, a intensidade da organização parental, a importância da associação com o passado, a inflexiva repertoriação dos entremeios discursivos ancestrais e a suficiência da pessoa no ambiente.

${ }^{8}$ Cartão postal, gelatina/prata. Coleção Daniela Moreau. Disponível em: https://www.metmuseum.org/art/ collection/search/650361. Acesso em: 14 de abril de 2020.
} 
Tal como escreve Edwards (1997), as conturbadas imbricações entre os discursos visuais e o agente antropológico determinam a fotografia africana ao longo de sua história. Mas os discursos da pose, as performances visuais e a valorização da pessoa, influências no trabalho dos fotógrafos africanos a partir de 1950, denotam a delicada importância da subjetividade, do encontro transcultural, da interpretação nomeada de si e da marca do sujeito na presença do olhar e da definição do observador. Em longo contraste com seu início etnográfico, voltado à instrução procedimental do registro, o olhar relaxa. A captura é cada vez mais suavizada no presente, as narrativas mostram-se menos naturalizantes e menos afeitas à vontade objetiva etnológica. Pelo prisma da fotografia e da vertente ensaística, o olhar é sentidamente mais ambíguo e dialógico - menos codificado no crivo da representação evidenciativa (PINK, 2001).

Seydou Keïta é essencial nesse movimento. A fotografia realizada pelo artista atualiza características étnicas, reencenando-as em uma dinâmica moderna e estetizante. Suas fotos são menos sobrevivências exóticas que teatros da memória - composições delicadas que reorganizam os elementos tradicionais das culturas malinenses, dotando-os de expressividade própria. Em um endereçamento sutil e sensível da identidade, habitado por jogos de figuração e afabilidade, a fotografia torna-se um procedimento de interposição - relaxado, desejante, permissível -, de afetividade alegórica. Em várias situações composicionais, a afeição de Keïta pelos retratados se une à delicadeza das imagens e ao apuro visual do ato de cena. As capturas constroem uma fotografia carregada de economia visual libertária, que aprofunda os espaços dialógicos e permite às histórias individuais serem entrelaçadas com os discursos étnicos. Às vezes sutilmente simétricas e potentes na diagramação da cena, em outras ensaiadas na costura com a moda e o cinema - em um jogo de influências ocidentais ressignificadas na circulação posterior das imagens -, as fotos trabalham sempre em prol da valorização da pessoa, de sua relação com a figura apresentada, da agência permitida e da própria densidade da inscrição. Keïta permite que os sujeitos retratados sejam capturados em encenações sutis, correlacionando, por exemplo, a religiosidade e as vestimentas tradicionais com as transformações socioestéticas nos objetos ocidentais exibidos com orgulho.

Entre muitos exemplos possíveis, há, pelo olhar do artista, uma construção correlata unida à pujança presencial. Os retratos de homens e mulheres da sociedade malinense de então irrompem como figuras únicas no modo como se apresentam na imagem pós-colonial, projetando uma negociação intensa entre o moderno e o tradicional. Com impressionante força retórica nas representações, os estilos africanos se apropriam da moda europeia e da dinâmica do olhar fotográfico, reorganizando-os a partir dos afetos, permitindo-os como situação presencial ${ }^{9}$.

0 ato de emoldurar é, aqui, associado à disposição palpável da visualidade que ressoa em uma atitude individual expressiva. Por vezes, a lente de Keïta mostra-se sensorialmente estendida ao circuito de afeições. A cultura dos ancestrais exibida em algumas roupas

\footnotetext{
9 As roupas e os acessórios são fundamentais nessa vinculação, sobretudo nos clientes mais jovens de Keïta: sucessivas vezes, os corpos são retratados próximos às motocicletas (símbolo inegável da transformação moderna), com um amplo repertório de vestimentas (trajes com corte ocidental para os homens, vestidos pret-à-porter para as mulheres), com o uso de pulseiras, anéis, colares, brincos e toda a sorte de adereços representativos das transformações socioestéticas.
} 
(na forma como o cabelo é arranjado para as mulheres, por exemplo) é reencenada com um vocabulário compositivo (enquadramento, distância, fundo, pose, gesto). Isto permite que exista uma imbricação dos sinais distintivos da tradição étnica e religiosa com a moda metropolitana e a cultura de massas. Os detalhes visuais, assim organizados, são significativos no gesto de identificar o personagem, explorando a convergência de elementos discursivos em princípio díspares. Elementos que, como atos de cena, transformam-se em densificações do posado: por exemplo, um vestido com motivos de miçangas é completado com um relógio de pulso vistoso e prateado; uma túnica branca é sutilmente rearranjada com um chapéu colonial; um lenço tradicional é a inscrição étnica em um porte avant-guarde.

A fotografia de Seydou converte-se, dessa forma, em uma espécie de teatro social (LEENHARDT, 2018) que aprofunda o contracampo possível, valorizando a individualidade e frustrando o imperativo do controle racial. Na elegância da leitura política, na cumplicidade entre fotógrafo e retratado, nos espaçamentos da violência colonial e no sinal de ressignificação contínua da etnicidade, a imagem torna-se manifestação do ensaio da busca de si, no qual o gesto que rememora a condição de pertencimento constitui, ao mesmo tempo, uma suficiência do novo ${ }^{10}$.

As fotos realizadas com as figuras emergentes do fundo, com motivos de ramagens, a estoica construção da cena e a fusão de estéticas (a modernidade a ser abraçada, a representação do passado nas marcas dos corpos e nos signos atemporais), junto ao chão de terra batida e a sutileza com que a cena é preparada, permeiam todo o trabalho como fonte de afetos. 0 efeito é a cumplicidade entre as estéticas europeias e a individualidade obstruída pelo passado colonial, sob o peso das tradições e a vontade expressiva pessoal.

Na lente do fotógrafo passam a ser importantes as apropriações estéticas da herança agressiva do colonizador e sua fonte de padrões distintivos ressignificados em composições particulares. 0 universo simbólico do colonizador é reestruturado na condição fluida da imagem estendida, e as imagens sensorialmente ensejam uma nova corporalidade, nascente e imorredoura, que desracializa os diagramas visuais impondo resistência política e expressão individual. Elementos da tradição antropológica (por exemplo, joias de uma aldeia) mostram-se, nesse sentido, distribuídos na luta pela narrativização pessoal, na apresentação do eu para a câmera, na elegância dos retratados e na liberdade ao alcance do efeito fotográfico sobre uma narrativa que é africana e moderna, interativa e transcultural, que mostra energia plástica e negociação intensa.

A galeria de retratos feita por Seydou, no efeito humanizador e irredutível da presença das fotos, transforma, nesse sentido, os retratados em figuras significativas; ao mesmo tempo, emissários de um povo e abertos à expressividade individual ${ }^{11}$. A cenografia e

\footnotetext{
10 Keïta também é um crítico do consumo exacerbado, e a multiplicidade de efeitos de pose instruída por arranjos informacionais do vestuário contracena com o empoderamento e a hierarquização da nova elite africana, dos jovens que exploram os sinais distintivos da modernidade europeia e do poder do consumo.

11 Não isenta, algumas vezes, de certa reprodução do diferencialismo europeu, pois a apropriação é realizada sob certa vontade de autossuficiência vestida pela tensão simbólica essencial: a estética ocidental captura os sujeitos, notadamente os homens, signatários de uma modernidade impossível.
} 
o entusiasmo pelo esboço da saída (ainda que parcial) da aberração do sistema colonial é compartilhada por fotógrafo e fotografado. Seydou enfatiza o jogo estético e político que há na tomada de posição sobre um ato de cena: suas imagens convocam e estruturam a presença diante da narrativa biográfica esgarçada na cultura. A dimensão ativa da sensibilidade é energizada pela pertença à tradição, pelo orgulho da pose e pela consciência crescente do lugar de resistência no jogo postural. Por exemplo, nas relações entre os sexos e as gerações: a foto da menina com o basin elementar e o pai de terno e gravata (figura 2) é de uma natureza comovente e, ao mesmo tempo, hierarquizada.

\section{FIGURA 2}

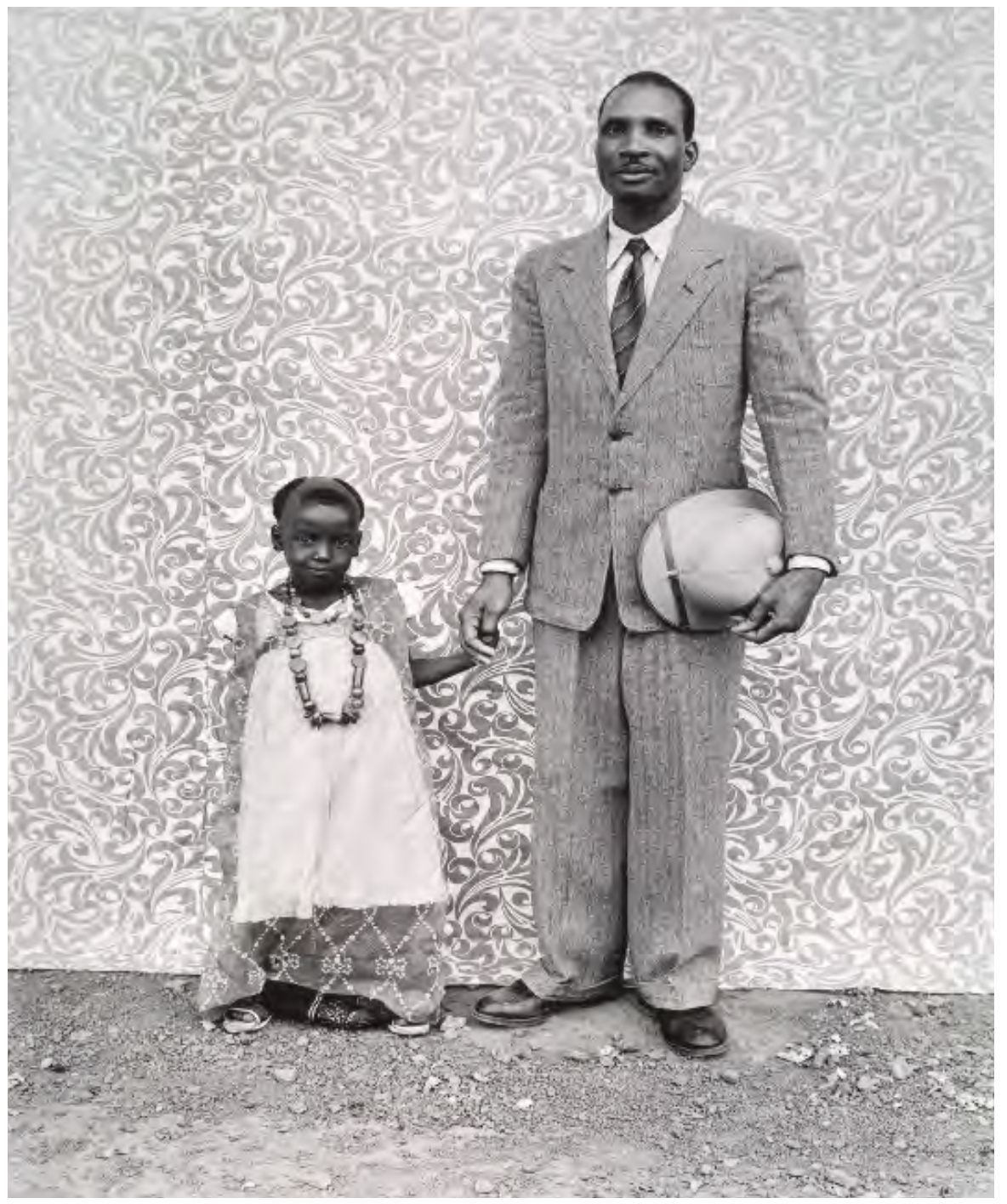

FONTE: SEYDOU KEÏTA. Sem título. Bamako, Mali, 1956-1957².

\footnotetext{
12 Fotografia/papel, gelatina/prata. CAAC - The Pigozzi Collection, Genebra. Fotografia do autor.
} 
Desse modo, os retratos de Seydou, a maioria realizada no fim do regime colonial junto à emergência dos fotógrafos africanos, inscrevem-se a partir das primeiras tradições do passado: fotografias de estúdio geralmente feitas com os fundos branco e em cores, adotando os corpos como se fossem consciências individuais e coletivas dispostas à intersecção do olhar. No efeito compositivo, na densidade com que a fotografia engendra uma busca pela atemporalidade iconográfica, os retratos vigoram a exaltação de uma autonomia nascente (o país em vias da descolonização). Os corpos são envoltos em uma atmosfera de afago e sensibilidade. Valorizam-se os gestos de cena, a postura crucial, os interstícios entre o moderno e o tradicional, ainda que a independência viria a acontecer gestada sob uma memória política exploratória. Mesmo assim, há espaço para o projeto nacional que se ensaia sob uma dupla intensidade: os rostos do passado (as vestimentas tradicionais), os liames com a modernidade (os trajes e símbolos do futuro), a expectativa do porvir (a fusão de estéticas) ${ }^{13}$.

\section{Do sutil retrato à lógica da africanização autoral: a moda bambara em Seydou}

Exploradas em uma trama de afetos, as imagens realizadas por Keïta deixam-se habitar pela onipresença do Ocidente e do narrador oculto (o fotógrafo preparador da cena, o retratado aberto à narrativa autoral). Toda possibilidade de agência está na centralidade da imagem particular, do círculo de relações do dress code e da consciência de um passado modelável. Nesse sentido, roupas, acessórios e cenários compõem a diversidade de aspectos da estabilização da memória - a partir de seus traços tangíveis, enlaçando a elegância tradicional com o esmero da composição e a atenção na biografia da pessoa. 0 ensaio com as vestimentas surgem em coexistência com a necessidade de apresentar os corpos narrados para o futuro livre e moderno. E o futuro é a expectativa de continuidade da tradição em um mundo ainda desconhecido, mas que se projeta nas tramas de um presente que exibe o elo de estéticas e a possibilidade do novo em diálogo com o perene.

Concentrada na pessoa, a fotografia de Keïta se destaca pela exaltação da intimidade. O sujeito está no centro da cena que implica em uma tensão de efeitos: com frequência, o chão de terra batida e o fundo com panos tradicionais criam uma energização possível, produzem uma veiculação individual - e, apenas individualmente, os sujeitos podem continuar o passado na interpretação do futuro, afeita ao pungente sentido estético da narrativa.

Nas fotografias do malinês, a diferenciação, portanto, dá-se em uma sensível linha de efeitos compositivos delicadamente exibidos na altiva apresentação do sujeito entre a memória do passado e a interpretação do porvir. É na finura da trama da matriz africana e ocidental que a narrativa se espraia em imaginários energizados. A arte do penteado, por exemplo, constitui uma fonte virtuosa da memória afetiva ditada pelo apelo tradicional. A maneira como o trançado é lido nas cabeças das mulheres adolescentes (as casadas, muitas

\footnotetext{
${ }^{13}$ Como escreve Agamben (2008), o tempo da moda, nesse sentido, está presente de maneira constitutiva face ao seu próprio avanço: o uso de vestimentas tradicionais e a criatividade no jogo de aparições fotográficas será, em Seydou, a "inacessível fronteira entre o pas encore e o ne plus" (AGAMBEM, 2008, p. 29).
} 
vezes, precisam usar foulard) exibe, por exemplo, uma modalidade social que entrelaça o passado remoto com a eminência do presente constituído pela possibilidade de ressignificação constante dos novos elementos, ou novos signos do presente. Keïta é quem desenvolve essa tradição, juntando-a em uma mesma cena: ao ajeitar um chapéu na cabeça de um indivíduo com túnica tradicional, ao preparar a cena em uma narrativa sensivelmente instruída, destacando os rostos e as mãos (raramente cobrindo as faces e os dedos), apresentando os sujeitos em seus moldes típicos, mas não os congelando em um registro evidenciativo ${ }^{14}$.

$\mathrm{O}$ ato de posar, portanto, tem a ver com a possível naturalidade do entrecruzamento da confiança no fotógrafo africano e a necessidade de lançar ao mundo uma aparência emergente - uma autossuficiência digna e protetora dos sujeitos retratados. Entre a experiência e a memória, os corpos desfilam seus mundos imaginários repletos de transparências, estreitamentos, imbricações do passado em um futuro sonhado/possível. A ancestralidade dos fotografados surge em recorte com a ambiguidade fotográfica (FONTCUBERTA, 2016) e com a condição de narradores da própria história ${ }^{15}$.

Keïta torna os sujeitos fotográficos marcadamente narrativos no atravessamento de tradições. Seu olhar composicional refreia a evidenciação e pousa na sobrevalorização da individualidade, na possibilidade representativa comunal e na sobrevivência dos afetos. 0 rosto feliz do homem com turbante islâmico fotografado junto ao bebê de colo, por exemplo, é uma dessas ênfases que existem na situação fotográfica determinada a explorar efeitos e afetos; a importância sóbria da conhecida fotografia do rapaz com terno branco, óculos com moldura encorpada, relógio de pulso e caneta esferográfica na lapela exibindo uma flor solitária, imiscui-se na tradição de retratos sensíveis e subjetivantes; e a fotografia das moças sentadas na motocicleta vespa, sorrindo felizes com o delicado relógio de pulso, os óculos escuros estilo browline e a importante bolsa de couro, é repleta de narratividade pessoal e ao mesmo tempo ensejo intérprete (figura 3).

0 apelo à moda europeia nos ternos dos homens, os acessórios (especialmente bolsas, óculos e sapatos para as mulheres mais jovens) e os símbolos de modernidade (motocicletas, automóveis, rádios transmissores, etc.) são, ao mesmo tempo, detalhes compositivos e anseios de consumo que revelam identidades e projetos, que exibem as preocupações com o futuro, com o desejo de permanência e o ímpeto de mudança.

\footnotetext{
${ }^{14}$ Como escreve Enwezor e Zaya (1996), suas fotos são leituras sensíveis do corpo tradicional em performances sutis encarnadas. Conscientes, modeláveis, questionadoras, repletas de experiência e emocionalidade, os corpos exibem o orgulho cultural na pragmática do endereçamento biográfico: os sujeitos vão e vêm, e a celebração da memória tradicional é realizada em uma autorreflexividade que faz uso da apresentação elegante entre dois universos.

${ }^{15}$ Celebrar a beleza é, nessas fotografias, uma ação realizada por meio das significações narrativas: no enquadramento cuidadoso que inclui os sujeitos e seus espaços constitutivos, suas subsistências mútuas, seus multiplicados laços nos desafios de continuidade e na distinção de experiências.
} 


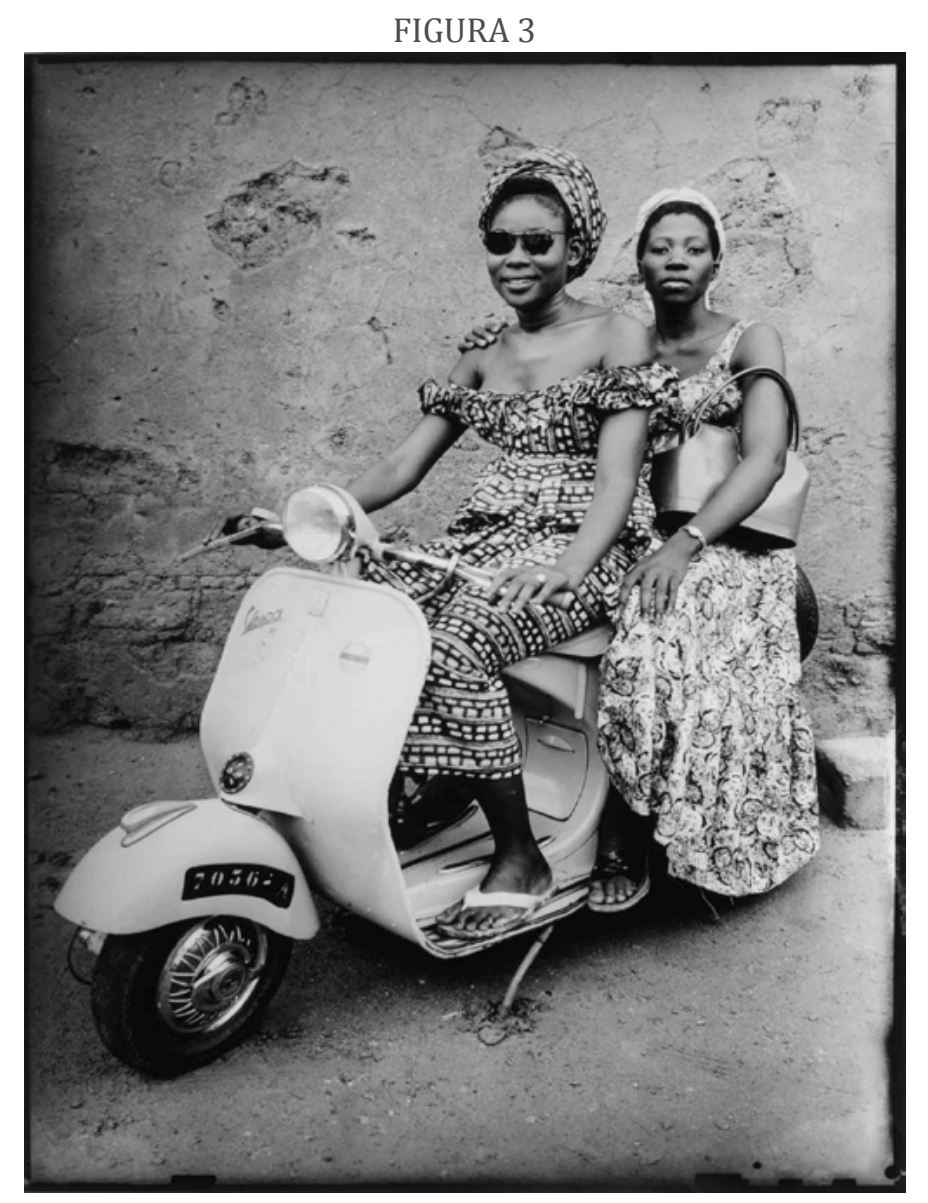

FONTE: SEYDOU KEÏTA. Sem título. Bamako, Mali, 1956-1957¹6.

Por exemplo, na famosa fotografia das moças nos ciclomotores - com frequência aparecem as marcas Solex e Lambretta -, a mise-en-scène mostra-se constituída pelo imaginário afropolítico de transformação da realidade tradicional (caracterizada pelos vestidos) e a sofisticação moderna (os signos de consumo em cena). A motocicleta, a bolsa de couro, os óculos escuros e o delicado relógio de pulso são, sutilmente, gestos de reagrupamento das características antropológicas narrativizadas em uma abertura à modernidade imaginária. No registro de Keïta, as poses estão encenadas no comprometimento do passado com os emblemas futuros: uma motocicleta, oferecida no estúdio do fotógrafo, pode ser a possibilidade de emanação do pertencimento associado ao novo, assim como a mudança de posição social ${ }^{17}$. Como escreve Leenhardt (2018), as poses revelam muito do sentido de pertenci-

\footnotetext{
16 Fotografia/papel, gelatina/prata. CAAC - The Pigozzi Collection, Genebra. Fotografia do autor.

17 É preciso lembrar que, em sociedades de pequena escala, de regimes antropológicos compactos, o peso das tradições e a importância dos papéis sociais entre diferentes gerações tornam-se um fator cúmplice entre os indivíduos; nesse sentido, as adolescentes buscam expressão em uma cena que é ao mesmo tempo postural e atravessada pelo tradicional/arcaico e pelo moderno; os códigos de vestuário estabelecidos pela roupa são, assim, parcialmente rotos pela gradação dos objetos intermediários (bolsa, relógio e óculos escuros); há liberdade e também vinculação, como se os corpos entronizassem, politicamente, tanto os lugares tradicionais como a autoafirmação associativa, configurando duplamente o pertencimento.
} 
mento e também da excitação agencial. A linguagem específica da construção da cena permite, com frequência, que o mundo vindouro, materializado nos objetos socioeconômicos, seja precursor das transformações sociais, especialmente para os jovens e as adolescentes encantados com os novos itens mercadológicos.

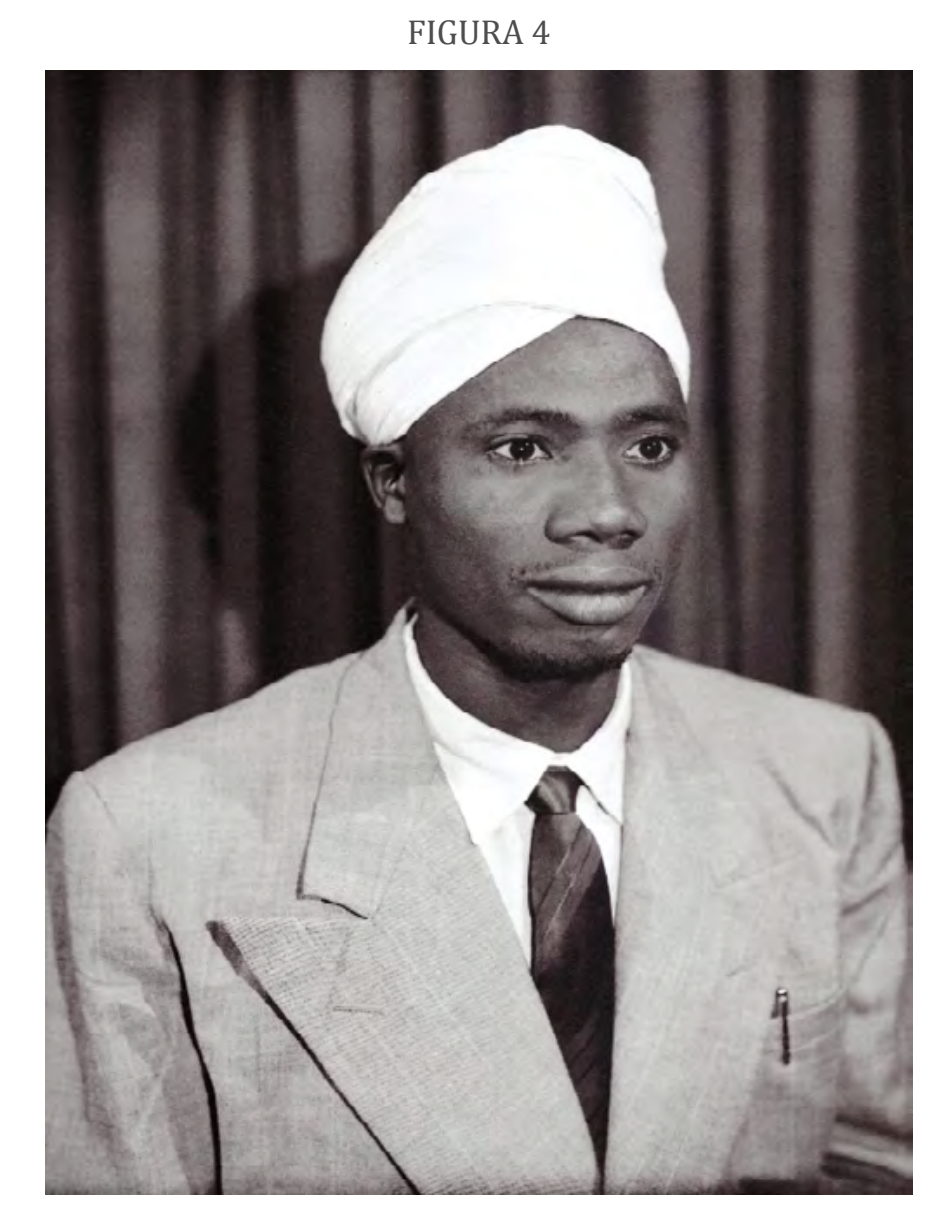

FONTE: SEYDOU KEÏTA. Sem título. Bamako, Mali, 1956-1957².

Na fotografia do homem com o turbante branco, terno e gravata e caneta no bolso, o retrato, tomado na sutil diagonalidade da pose, exibe o rosto de um jovem que aciona os elementos modernos com o rigor do código religioso (o turbante tradicional). A fotografia é ao mesmo tempo delicada e respeitosa com o signo religioso e aberta para a construção particular. 0 esmero da foto se traduz na contenção da gestualidade, no rosto de feições suaves que, com o uso do turbante, remete ao valor simbólico do passado. No período histórico que a foto foi feita (década de 1950), o papel do homem, sob a influência da religião islâmica, está afeito ao modelo de retratismo masculino em toda a África (KELLER, 2013). Os rostos geralmente são capturados em seriedade facial, as mãos não aparecem em destaque, a postura é normalmente tomada em pé. Mas, na captura de Keïta, a suposição hierárquica é, também,

18 Fotografia/papel, gelatina/prata. CAAC - The Pigozzi Collection, Genebra. Fotografia do autor. 
transformada pela referência universalizante do traje (terno e gravata), fazendo com que a produção torne-se ao mesmo tempo protetora e aberta. Assim, o sujeito em representação parece buscar uma identidade concentrada nos dois âmbitos de influência. Nesse sentido, não há um tipo social definitivo nas fotografias, pois, como escreve Leenhardt (2018), as figuras masculinas de Keïta anseiam pela autoafirmação orgulhosa do passado entronizado, mas simultaneamente rompem com a esquematização ao revelarem certo constrangimento na pose, certa vontade de captura mesclada com aderência ao moderno ${ }^{19}$.

\section{FIGURA 5}

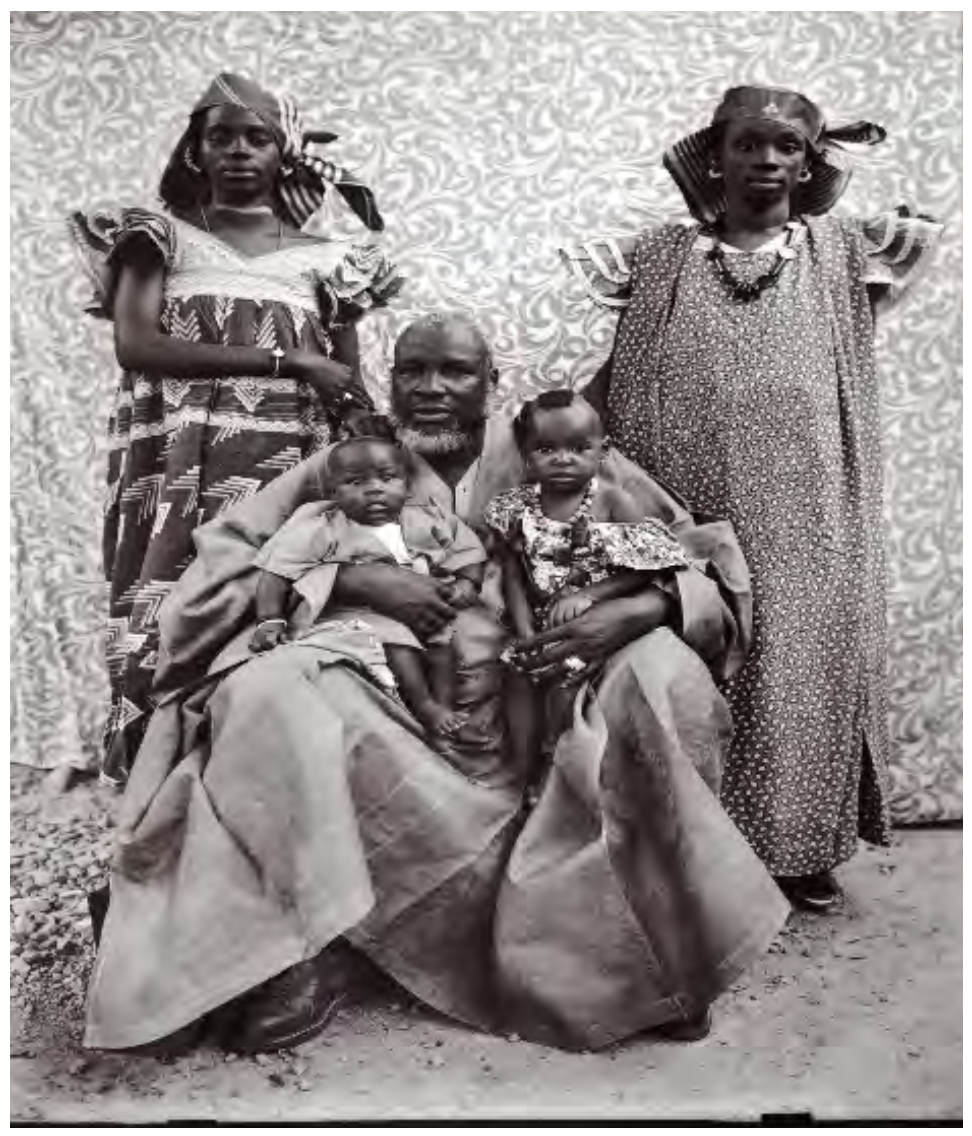

FONTE: SEYDOU KEÏTA. Sem título. Bamako, Mali, 1956-1957²0.

No caso do retrato em família (figura 5), a função social do chefe tribal pode ser observada no poder em cena destinado ao homem: a centralidade do corpo na composição fotográfica, ao lado do qual estão as duas esposas em pé, com as crianças no colo. É consensual

\footnotetext{
19 Para os homens, os chinelos e as botas militares, os relógios de pulso metalizados, os quepes e as boinas de origem ocidental, a antiga espingarda de caça (exemplo máximo do poder colonial), além de elementos religiosos, revelam um sistema de evidenciação que mistura o espaço anterior com o poder dos novos códigos.

20 Fotografia/papel, gelatina/prata. CAAC - The Pigozzi Collection, Genebra. Fotografia do autor.
} 
para o fotógrafo a representação indumentária e o enlace com o passado, a memória étnica, a possibilidade de aliança com o futuro - como no sapato de couro advertido no pequeno destaque da imagem em seu primeiro plano inferior.

A fotografia do pai com a filha (figura 2), por sua vez, remete aos espaços de decoro e ao sonho de liberdade e modernidade que existiam em determinado contexto histórico da África pré-Independência. 0 pai segura delicadamente a mão da filha, é retratado diante do fundo têxtil, cortado pelo chão de terra batida em que os pés calçados do homem dividem lugar com as sandálias da criança, vestida com roupas tradicionais. Nessa composição sutil e modelada, a delicadeza da narrativa reúne elementos antigos e modernos. A cena é paginada como uma criação visual que essencializa as figuras e ao mesmo tempo as interpreta em seus lugares de afeto, permeando um corpo completamente vestido à europeia com uma criança em sua harmonia cerimonial. 0 elegante vocabulário visual de Keïta, nessas duas fotos, pode ser observado no status que as imagens alcançam como configuradoras de sentido, reivindicando o papel atribuído aos sujeitos biográficos, às práticas populares e às novas experiências com a modernidade vestimental.

FIGURA 6

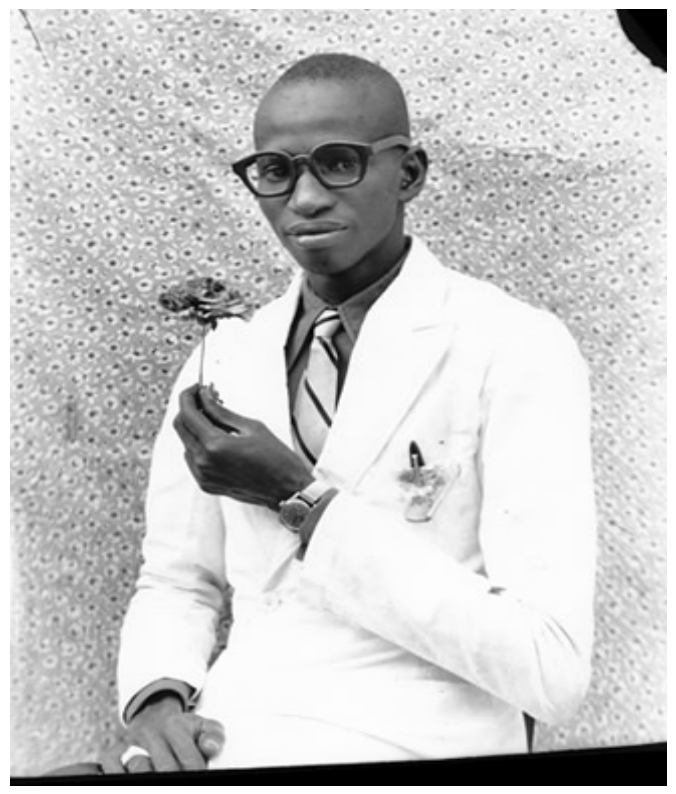

FONTE: SEYDOU KEÏTA. Sem título. Bamako, Mali, 1956-1957²1.

Provavelmente a fotografia mais conhecida de Seydou, a do jovem segurando uma flor, vestindo terno branco e acessórios (caneta sobre lenço com desenho de ramos de flores, relógio cromado de pulso, óculos de grau, etc.) (figura 6), em um enquadramento sugestivo, revela uma delicadeza ímpar, costurando o documento histórico com a manifestação artística.

\footnotetext{
21 Fotografia/papel, gelatina/prata (ampliação feita em grande formato, $120 \times 180 \mathrm{~cm}$, a partir de negativo original pelo laboratório Picto, com supervisão do autor, em 1995. CAAC - The Pigozzi Collection, Genebra (fotografia do autor).
} 
Em um gesto em pose de grande riqueza e sensibilidade, a captura mostra a sentida feitura da imagem estabelecida no primor da representação visual. Adivinha-se, aqui, um sorriso e uma alegria da encenação. A narrativização discursiva se faz em uma autoafirmação sutil, em um jovem com postura performática que momentaneamente quebra o jogo da representação impondo seu olhar afetivo e fotográfico - paralelamente plástico e subversivo, paralelamente africano e moderno. Sua presença em cena faz emergir uma africanidade que suspende os glossários tipológicos e rompe a designação tribal em relação ao papel masculino.

Concentrada na emocionalidade do retrato, o moço é teatralmente sobreposto no fundo com o tecido $w^{2} x^{22}$. 0 cenário preparado no estúdio de Keïta ensaia um esquema visual que permite ao sujeito programar a posição social desejada, e, simultaneamente, revelar sua condição biográfica. É na segurança do estúdio e na câmera-artefato que o paradigma da autenticidade emula uma possibilidade de estetização da imagem. 0 jovem segura a flor, seu gesto é único. Seu gesto é livre. É a liberdade da recusa exótica na qual a preponderância da pose se dá sobre a pictorialidade narrativa, na qual a africanidade não significa nada, senão levar em conta o espaço imaginário e a beleza atemporal em uma condição de integridade identitária.

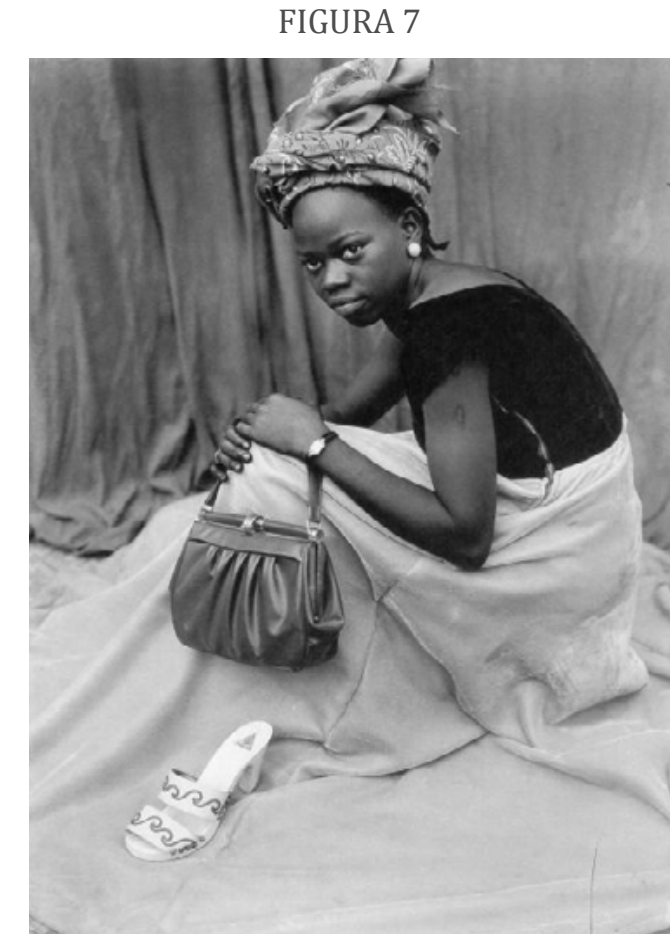

FONTE: SEYDOU KEÏTA. Sem título. Bamako, Mali, 1956-1957²3.

\footnotetext{
22 Tecido com padrões específicos, geralmente geométricos ou com pequenas formas entrelaçadas, proveniente da Holanda e disseminado por toda a África Ocidental como elemento de grande valor cultural a partir do fim da década de 1940, introduzido após a chegada de navios no golfo da Guiné. Atualmente, é bastante difundido pelas indústrias Vlisco, perdurando em estamparias que se tornarão clássicas e repetidas por várias gerações, transformando-se elemento significativo na vestimenta africana.

23 Fotografia/papel, gelatina/prata (ampliação feita em grande formato, 120 x $180 \mathrm{~cm}$, a partir de negativo original pelo laboratório Picto, com supervisão do autor, em 1995. CAAC - The Pigozzi Collection, Genebra. Fotografia do autor.
} 
Na fotografia da moça com a bolsa de couro, o relógio de pulso, o sapato branco e o brinco de pérola (figura 7), os adereços são tão fundamentais quanto a roupa exibida. A jovem é registrada em uma postura elegante, deixa-se capturar em uma pose elaborada, e toda a harmonia da foto está entretecida na intenção projetiva da imagem social. Aqui, os acessórios são significativos para a experiência e a codificação da modernidade ansiada. Nesse aspecto, é extraordinário que o retrato seja feito com uma delicadeza compositiva clássica, e, ao mesmo tempo, permita a subjetividade narrativa, pois a moda do pós-guerra na fotografia africana ainda está apenas parcialmente influenciada pela criação de uma cena que já é comum nas revistas de alta-costura ocidentais do período. No entanto, na foto realizada pelo artista, a imagem ganha polissemia representativa. A toma é feita com uma autossuficiência impressionante, dispondo o vestuário ocidental (e os acessórios de consumo) junto ao tradicional lenço na cabeça. 0 lenço reforça a inserção visual da memória étnica e do papel social feminino na África, mas é sentidamente posto em evidência em uma captura que investe em uma construção cosmopolita. A referencialidade do arranjo, nessa perspectiva, está composta tanto pela sinergia com o passado imemorial quanto nos modelos visualizados nas revistas ocidentais da época, e pela multiplicidade de referências culturais abraçadas em uma visão permissiva da incorporação ${ }^{24}$.

A aspiração do sonho do Ocidente, mesclada com a perfeição do estilo e da alegria do New Look no Mali, endereça os corpos em um universo de valorização da perspectiva moderna e biográfica e permite que a memória étnica seja lida na contenção extraordinária da imagem. Essa dupla suficiência - autoral e textualizada - abre espaço para a construção subjetiva como resistência política e ação artística. Em termos de experiência estética, a fotografia realizada por Seydou enseja tanto uma potência emblemática e codificada quanto uma vontade de individuação criativa da pessoa retratada. A energia sensorial da imagem aciona, nesses termos, uma transformação possível do posicionamento individual e do registro íntimo, interpretando-a na interação transcultural. A moda revela-se, no campo dos sentidos, como um recurso para a expressividade autoral e o tratamento criativo, conseguindo emular a vontade moderna em concordância com o respeito etnográfico. 0 vestuário, assim, encaminha a personalidade da moça retratada, valorizando a contribuição da vestimenta em um contexto que as referências servem tanto para, como escreve Barthes (1983), se aproximar como para se afastar do costume ${ }^{25}$.

Ao mesmo tempo que vestem o corpo humano e se tornam ato de comunicação, as fotos permitem a expressividade autoconsciente do desejo de ocidentalidade em uma personalização africana. Conseguem desenvolver a modelagem pessoal face a uma apresentação pública

\footnotetext{
${ }^{24}$ Como escreve Grosfilley (2018), na África Ocidental, a moda francesa e a americana circulam por meio das revistas de comportamento. Respira-se "certo sonho de Ocidente", bastante visível na sincronização com as imagens de celebridades como Cary Grant e Gary Cooper; o uso ostensivo de objetos de luxo, tais como relógios de pulso, canetas pluma e cigarreiras, assim como luvas brancas para as mulheres e gravatas para os homens, informa a identidade social na aspiração da alfabetização, na celebração do corpo (contrastada com certo pudor fixado pelos missionários), na feminização onipresente e na reapropriação criativa da moda para ensejar tanto ascensão social quanto características identitárias.

25 Muitas das fotografias do artista são realizadas com os sujeitos em suas roupas tradicionais, por exemplo, com os bubus característicos; espécies de mantôs que servem para cobrir quase todo o corpo, e que respondem ao sistema de maturidade e notoriedade (GROSFILLEY, 2018), os bubus surgem em várias fotos e parecem desempenhar o papel de transmissão de genealogias, relativizados pelos acessórios ocidentais e por certa costura da pose com a pulsação interétnica.
} 
do corpo, reconstituída pela toma em estúdio e no endereçamento com a identidade a ser narrativizada. A fotografia deriva, de tal modo, em uma sensitividade plástica e emocional que paralelamente costura a pessoa, retirando-a do anonimato e ativando a responsabilidade comunitária e tradicional em refinada reapropriação criativa da moda do Ocidente de então.

Segundo Grosfilley (2018), no contexto de acelerada urbanização do Mali nos anos 1950, em um universo que começa a ser cada vez mais globalizado, as imagens de Keïta subjetivizam e se associam com variadas referências culturais. Entre o passado (duradouro e emotivo) e o futuro (aberto e em permanência), os vestuários e os acessórios ajudam a caracterizar e também a romper com determinada visão de grupo e de inscrição dos papéis tipológicos nos esquemas sociais característicos. Nessas fotografias, o corpo, portanto, nasce como uma caracterização que ensaia o pertencimento e sua perda relativa, abrindo-se ao discurso da memória e da narrativa individual. Esse nascimento é repleto de formas sutis de atravessamento, prolongando a aspiração biográfica no imaginário sensível das tomadas sugeridas, na empatia com os retratados, na elegância da captura, que significamente compõem os elementos da fotografia (enquadramento, posição, distância, gestualidade, etc.) valorizando tanto a duração da atmosfera memorial como o imaginário intersubjetivo.

Criar a fotografia, aqui, é poder disseminar uma operação visual que permite ao sujeito encontrar seu melhor/próprio espelho, conferindo à participação individual seu sonho de assemelhação, em uma equivalência possível, aberta, reapropriada, criativa, ancestral e versável - simples e embelezável - tanto na imagem como em seus laços de intimidade.

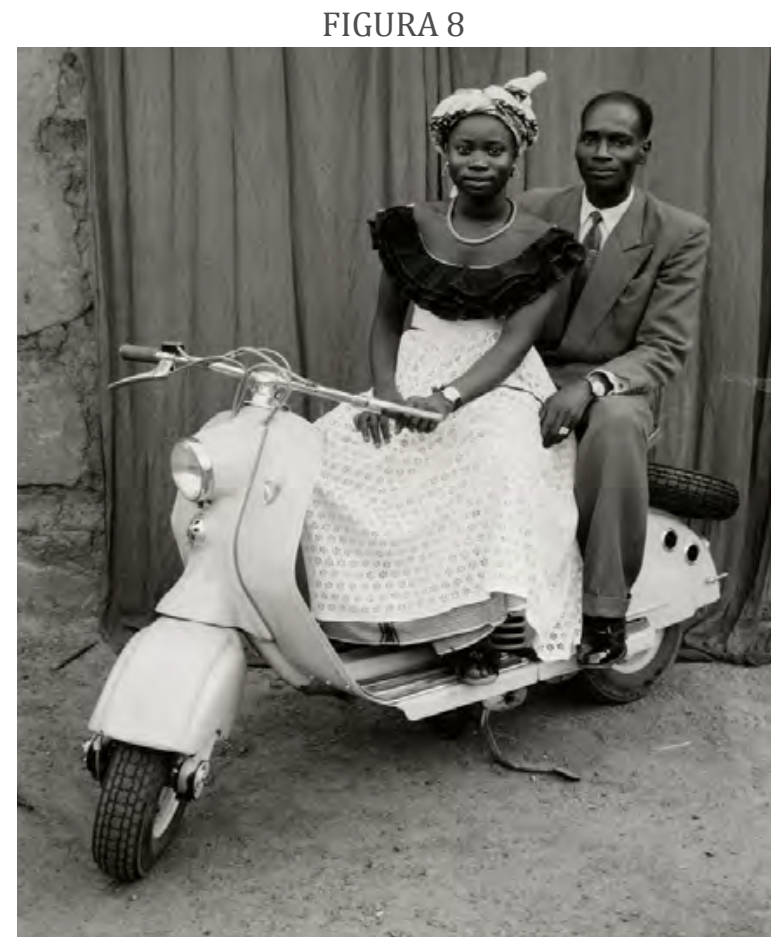

FONTE: SEYDOU KEÏTA. Sem título. Bamako, Mali, 1956-1957²6.

${ }^{26}$ Fotografia/papel, gelatina/prata. CAAC - The Pigozzi Collection, Genebra. Fotografia do autor. 
$\mathrm{Na}$ fotografia da moça e do rapaz na motocicleta (figura 8), os discursos da pose são subjetivados em um enlace do passado a ser respeitado com o futuro a ser aberto. A moda metropolitana está interpretada em um cenário preparado para o registro onírico e consciente, engendrada com o momento presente da alegria moderna: há espaço para acolher o desejo de transformação, há um domínio socioestético que respeita os corpos e modela as figuras, pondo-as em uma insistência intersubjetiva carregada de sensibilidade. Os olhos, calmos, presentes e tímidos do casal refazem o desejo de pertencimento e também de identidade. Ambas as figuras vestem suas roupas preparadas com esmero, de certo modo interpretando papéis clássicos e transformadores: a moça senta na frente da motocicleta, pousa suavemente uma das mãos no guidão, girando-o para a direita, enquanto o vestido chama atenção por causa da sua aparência nova e cuidada; o homem ocupa o assento traseiro, toca delicadamente com uma das mãos a saia da moça, seu paletó foi vestido com apuro. Os complementos, os dois relógios de pulso: a sofisticação programada e afetuosa da cena também é vista nos olhos dos jovens, vestidos com uma memória anterior, celebrando a intimidade e a cumplicidade da foto na forma como olham o fotógrafo e instam seus mundos convolutos e ressoantes.

Os sujeitos, os corpos, os entes narrativizados, nessa situação ao mesmo tempo empática e encenada, parecem ser atravessados por uma sensação biográfica e comunitária. 0 fundo caprichoso com a cortina delicada, sem deixar completamente impedida a visão das paredes lanhadas nas laterais, o chão de terra batida, as pequenas pedras polvilhadas por todo o solo, a motocicleta seminova (símbolo inconteste do orgulho da ressignificação) e as figuras que olham com suave comunicação o mundo a ser buscado enlaçam o tempo passado e o circuito presente em um registro vicário, comum, em pausa, que procura a essência que os defende, que circula a imagem que os carrega.

No limite, esse e também muitos outros retratos de Seydou envolvem a fotografia, a moda e o diagrama do pertencimento em um resumo de substâncias ao mesmo tempo físicas e espirituais, paralelas e biográficas. Esgarçadas na promessa de um tempo que enlaça o passado e o presente, que adivinha o futuro no desejo de autonomia, faz a imagem ser uma memória outra, um símile entre afetos, uma ação artística e comunicativa que, na afinidade estilística, na empatia do fotógrafo e suas lentes estésicas, coloca em movimento a reciprocidade (des) equilibrada, a partilha de sensibilidades sucessivamente emitidas no gosto de estar junto - de dizer sobre a capa mais profunda e a explicação mais relativa. Ou, também, em programar virtuosamente a cena para deixá-la ser atravessada, de modo constante, na liminaridade de toda a distinção, de toda a expressão cultural, de todas as agências comunicáveis.

A emersão suave dos personagens de seus fundos visuais muitas vezes precários e improvisados, elegantemente vestidos e distribuídos em atos de pose profundamente elaborados, concentra boa parte da energia relativizadora dos retratos que ensejam os sujeitos em suas vidas cotidianas, sentidas e programadas, repletas de oportunidades e o devir de novas formas. A maneira cúmplice e delicada com que participam do jogo fotográfico, a alegria com a qual aderem ao projeto do fotógrafo e a possibilidade de cumprirem suas funções tradicionais em consonância com o desejo individual de ressignificar as atuais influências e as transformações dos corpos (certo sonho de Ocidente abraçado em uma individualidade própria) estão profundamente entrelaçadas em uma leitura estética e política do cruzamento de influências. 0 palco possível da transformação que se ensaia em uma africanização 
terna e respeitosa no plano dos sujeitos abre-se ao ato fotográfico como materializador de essências a serem cumpridas, de distâncias a serem rotas.

Permitindo a moda como sugestão de um sistema de ação cuja proposta maior é ler o mundo e habitá-lo com personagens inesperados, cúmplices e biográficos, em suas fontes interativas e sociais, Seydou foca a energia representativa da imagem e sua ressonância em um mundo/universo a ser escrito. Personagens apresentados no jogo de mensagens compartilhadas, no prólogo do mundo interno e na vontade de reação estética, de autonomia sobre o destino livre e individual, de agência diante da linguagem e da linguagem (modal, contidamente performática, transgressivamente imitativa) como a possibilidade de lançar na África de então, que olhava para o futuro a ser escrito a todo instante, o orgulho autodeterminado da independência e da renovação. Essa forma de endereçamento que é, em uma feitura de imagens solícitas e repartidas, disponíveis e condescendentes, e que nunca existem além de suas manifestações nas interações sociais (GELL, 2018). Essas formas e fontes de afeto que mobilizam seus princípios e longevidades na circulação do encontro e na valoração do íntimo.

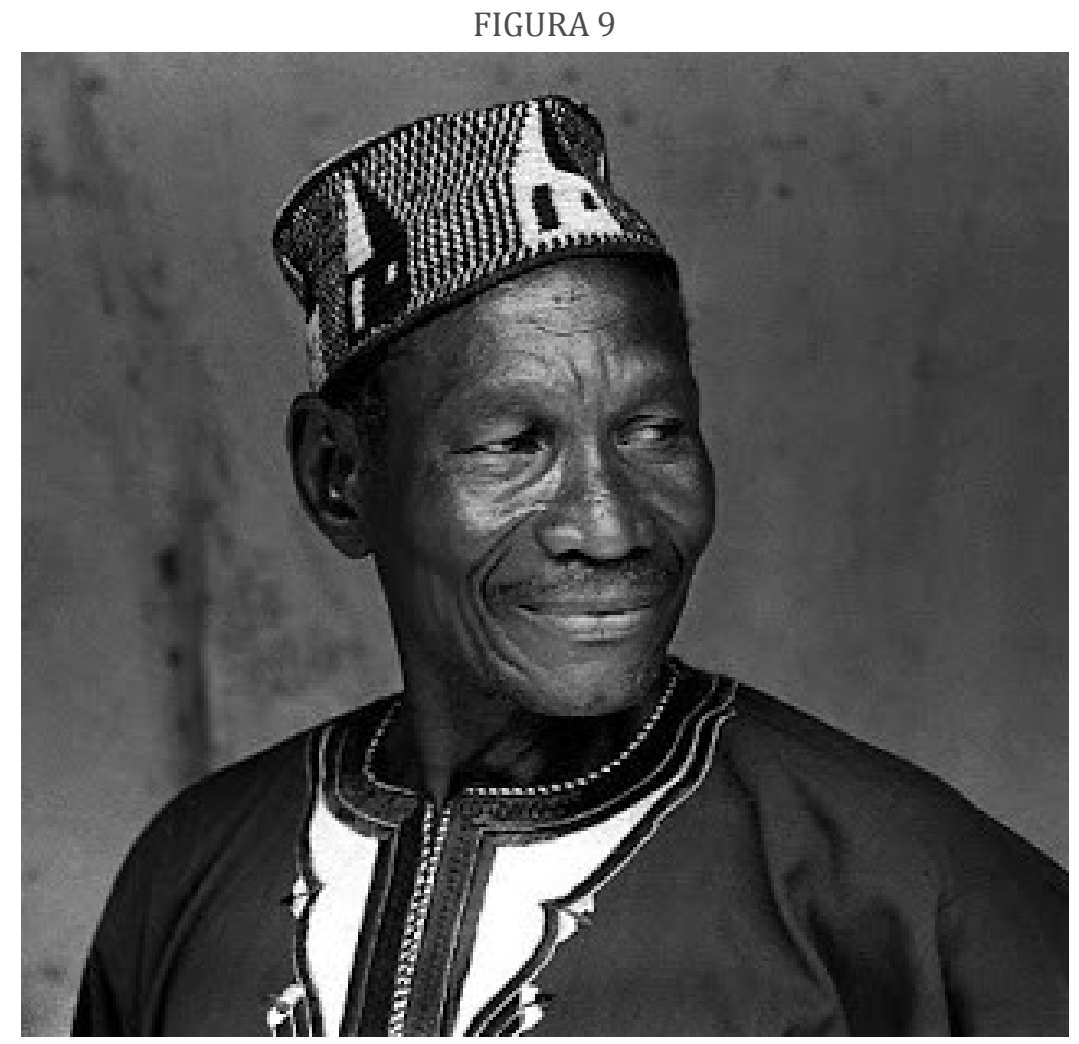

FONTE: PHILLIPPE SALAÜN. Seydou Keïta. Bamako, Mali, $1998^{27}$.

27 Fotografia/papel, gelatina/prata. CAAC - The Pigozzi Collection, Genebra. Fotografia de Phillippe Salaün.https://www.mutualart.com/Artwork/Seydou-Keita-et-Malick-Sidibeamako/DA5839208A3FEF49. Acesso em: 14 de abril de 2020. 


\section{Considerações finais}

No fascínio pelo moderno, a história da fotografia africana se impõe vagarosamente: expressa sua urgência em fotógrafos como Keïta, que manejam uma tradição que precisa lidar com as rápidas modificações na intensificação do contato com o universo europeu. Nesse sentido, duelam com a memória e o passado de usurpações, estimulando uma autonomia representativa pelas lentes africanas. Os corpos retratados rememoram, vinculam e ressignificam o passado no presente, diante de uma cumplicidade negociante que vê a onipresença antropológica do fotógrafo e do fotografado como os principais agentes históricos.

Nesse sentido, a intensidade plástica dos retratos de Seydou Keïta, esgarçados em composições fotográficas e com sensibilidade e virtuosismo ímpares, valoriza a etnicidade e a onipresença da memória fotográfica em coexistência com a representação da pessoa. Ensejam modulações antropológicas no cotejo com a arte indumentária tradicional africana, e revelam um sutil atravessamento entre a disposição documentarista e a performance das construções dos corpos. Aqui, é valioso destacar que, em termos de representação, essa imagem é importante pois faz evidenciar a moda como circulação narrativa corolário da dimensão dos objetos apropriados. Uma parcela dos retratados utilizavam acessórios que não eram próprios, mas que faziam parte de vontades de consumo (importantes para a entrada em certa modernidade da época). Eram utilizados por Keïta, e por muitos fotógrafos africanos durante os anos de abertura, como elementos retóricos que respondiam por certo circuito de representações que, pertencentes ao estúdio, marcavam trânsitos e relações fora dos domínios da moda da África Ocidental. Em certo sentido, os adereços e roupas sugeridos para a construção da cena destacam o jogo como os códigos da moda eram feitos - relativizando, inclusive, certa dimensão específica da moda africana.

O endereçamento de aspectos estéticos (as roupas e seus acessórios) e a valorização dos rostos, dos corpos, da pose e da explicitação da autonomia conferem uma potente relação, algumas vezes enfrentando, outras sublinhando (mas sempre produzindo constâncias subjetivantes) o imaginário da cultura de massas e da cultura da imagem europeia dos corpos malineses. Entre a reapropriação criativa de estilos europeus e a reenergização das tradições indumentárias africanas, as fotografias de Seydou, abraçadas na longevidade da difusão artística, enlaçam passado, presente e o futuro de então em uma ativa correspondência da transmissão de genealogias, em uma multiplicidade de referências culturais, na encenação da moda daqueles anos como um dos mais importantes aspectos da narrativização discursiva e da autoafirmação da pessoa étnica, da imagem cúmplice, da transformação individual.

As fotografias, realizadas durante o período de emergência da alegria independentista, permitem um lugar a mais no entendimento da narrativa particular, na busca pela autodeterminação imagística, na africanidade desejada em papéis possíveis e em subversões suaves. A moda surge como um devir comunicativo e sentimental, que enlaça o sonho de autonomia nacional com a possibilidade de designação dos discursos pessoais. Mas isso é construído a partir das representações e do encaminhamento dos objetos e acessórios que circulavam em práticas de consumo, ou, ao menos, de vocabulários visuais que se organizavam desde a ideia de representação em uma gramática de cena preparada no estúdio. A circulação dos signos respondia a uma relação da moda com a resposta do fotógrafo e a 
vontade do retratado, provavelmente diante da importância da abertura: ser moderno, apropriando-se de elementos considerados de diferenciação social e certa modernidade ocidental.

Dentro de uma estética que valoriza o passado e ao mesmo tempo permite o cotejamento com o futuro, os corpos são enquadrados em uma sensível busca pela interpretação do estilo individual com a narrativa cultural em voga, refinando influências e circulando os motivos e aspirações de consumo, as performances pessoais, a alegria da pose. Sempre com a dignidade dos sujeitos com indumentárias tradicionais e dos jovens africanos, a fotografia torna-se ato de imagem: referenda a fascinação pelo novo, materializa e permite a imagem social em termos reapropriativos e vinculantes.

Os retratos de Keïta, afetuosos ao ponto de diagramarem a variação e a permanência, acolhem o indivíduo, abraçam a genealogia, restituem a multiplicidade de referências culturais em um discurso clássico e também projetivo. Discurso este que nunca se afasta da etnicidade e da condição irredutível do pertencimento, ensejado no jogo das representações disponíveis pela moda e seu apelo a uma modernidade outra. Isto é, práticas esgarçadas nos termos de uma relação negociada em diferentes contextos de interação que replicam um imaginário a ser vestido. No limite, situações que aprofundam a identidade no jogo possível entre o costume e a atualização em seu sonho de reconhecimento - em sua relativização possível, em sua modelagem na empatia entre a expressividade de quem posa (quem particulariza o tempo e a indumentária), e quem busca o retrato.

O corpo - e a foto - tornam-se, aqui, consciências modeláveis: ao mesmo tempo, a exterioridade movida para dentro (da imagem que a cristaliza e a torna transmissível) e a intimidade que se vê de fora, no trabalho do afeto, na delicadeza e na consequência da preparação e seu registro (na cumplicidade permissível, proeminente e identificada entre autorreflexão e experiências). Um ato de espelho como um ato de fluxo. Esse espaço essencial, emocional, social, cultural e estésico. Nas fotos de Seydou, a intensa convocação dos signos e da memória a ser enlaçada. Em uma pujança de expectativas. Em um cumprimento de pose e afirmação de envolvimentos. 


\section{Referências}

AGAMBEN, Giorgio. Qu'est-ce que le contemporain. Paris: Rivages, 2008.

BARTHES, Roland. Système de la mode. Paris: Éditions du Seuil, 1983.

EDWARDS, Elisabeth. Beyong the boundary: a consideration of the expressive in photography and anthropology. In: BANKS, Marcus; MORPHY, Howard. Rethinking Visual Anthropology. London: Yale University Press, 1997.

ENWEZOR, Okwui; ZAYA, Octavio. In\sight: african photographers, 1940 to present. Nova York: Guggenheim, 1996.

FONTCUBERTA, Joan. La furia de las imágenes: notas sobre la postfotografía. Madrid: Galaxia Gutenberg, 2016.

GROSFILLEY, Anne. Têxtil e moda no Mali pela lente de Seydou Keïta. In: LEENHARDT, Jacques; TITAN JR., Samuel (orgs.). Seydou Keïta. São Paulo: IMS, 2018.

KELLER, Candace. Visual griots: identity, aesthetics, and the social roles of portrait photographers in Mali. In: PEFFER, John M.; CAMERON, Elisabeth Lynn (orgs.). Portraiture \& photography in Africa. Bloomington: Indiana University Press, 2013.

LEENHARDT, Jacques. Os retratos de Seydou Keïta: um instante de dignidade. In:

LEENHARDT, Jacques; TITAN JR., Samuel (orgs.). Seydou Keïta. São Paulo: IMS, 2018.

PINK, Sarah. Doing visual ethnography. London: Sage, 2001. 